by nearly a century the experiments of Sir Francis Ronalds at Hammersmith.

Gray's experiments had considerable influence on his contemporaries and on none more than on the French experimentalist Charles Francois du Fay (1698-1739).

Three events of interest marked the closing years of Gray's life. On November 23, 1731, when the Prince of Wales and the Duke of Lorraine visited the Royal Society, then housed in Crane Court and presided over by Sir Hans Sloane, among the experiments shown the distinguished visitors were those of "Mr. Gray, which succeeded, notwithstanding the largeness of the company", and about the same time Gray became the first beneficiary under the bequest of Sir Godfrey Copley, who when he died in 1709 left $£ 100$ to the
Royal Society "to be laid out in experiments or otherwise for the benefit thereof as they shall direct and appoint". The fund was not used for a medal until 1736, but Weld in his list of "Awards of the Copley Medal" places Gray's name at the head. The third event was the ad. mission of Gray in 1732 as a fellow of the Royal Society. That he had not been admitted before may perhaps have been due to pecuniary circum. stances and his position as a pensioner of Charterhouse; but, however this may be, it does not lessen our debt to him as a pioneer in electrical science, and one who predicted that what he was doing in minimus would, some day, be so extended that electrical phenomena would be made to resemble those of thunder and lightning.

\title{
Science in the Service of the State
}

$\mathrm{T}$ HE growing number of separate departmental reports issued by the research boards and stations of the Department of Scientific and Industrial Research, among which were included last year for the first time those of the Road Research Board and the Chemical Research Laboratory, enhances, rather than diminishes, the importance of the Annual Report of the Department. No other document gives such a comprehensive picture of the way in which science has been mobilised in the service of every aspect of our national needs, whether of the great departments of State, industry, municipal services or of the everyday wants of the home. The twentieth Annual Report of the Department* issued on December 30 covers the period October 1, 1934September 30, 1935, and contains the brief report of the Privy Council Committee, signed by the Right Hon. J. Ramsay MacDonald, Lord President of the Council, the longer report of the Advisory Council over Lord Rutherford's signature and summaries of the work of the National Physical Laboratory, the Chemical Research Laboratory, the various research associations and research boards or committees.

The gross expenditure of the Department in 1934-35 was $£ 719,276$ or $£ 549,781$ net, as against $\mathfrak{\$ 4 7 6 , 8 9 7}$ net in $\mathbf{1 9 3 3 - 3 4}$. In this, the National Physical Laboratory, with $£ 219,039$ gross or $£ 122,847$ net, is as usual the largest single item of expenditure; but the gross figure includes the cost

* Department of Scientific and Industrial Research. Twentieth Annual Report for the Year 1934-35. Pp. iv +185. (London: H.M. Stationery Office, 1935.) 38 , net. of work at the Laboratory for the Food Investiga. tion Board, the Radio Research Board, the Road Research Board and other research boards of the Department. Expenditure on the Chemical Research Laboratory was $£ 21,722$ net, on food investigation $\mathfrak{£ 3}, 539$, forest products research $£ 39,408$, and on fuel research $£ 83,984$, all net. Against gross expenditure of $£ 69,723$ on building and road research and $£ 11,769$ on water pollution research, receipts amounted to $£ 35,906$ and $£ 6,638$ respectively, while a further sum of $£ 10,847$ was received against expenditure on food investigation. The net expenditure on the Geological Survey and Museum was $£ 65,137$ and the centenary of the Geological Survey, the senior organisation of the Department, coincided with the opening in July of the new buildings in South Kensington for the headquarters of the Survey and the Museum of Practical Geology.

The work of the Geological Survey is funda. mental for all important schemes of civil engineering, mining and water supply, and is of direct interest to agriculture. It is the senior geological survey of the world, and no British scientific institution has more frequently served as a model for similar establishments both in the Empire and in foreign countries. In addition to re-surveying coalfields of Yorkshire, Lancashire, Cumberland, Northumberland, Forest of Dean, Forest of Wyre, Fifeshire, Dumfriesshire, Stirlingshire, Ayrshire and Lanarkshire, an exceptional number of inquiries on water-supply and inspections of borings for water have been dealt with as 
a result of the drought. The application of geology to the study of soils has also continued jointly with the soil experts of the Development Commission.

Grants to the research associations amount to $£ 85,384$ net as against $£ 58,992$ net in $1933-34$, and developments in connexion with this movement are the most encouraging feature in the present report. Since the Advisory Council made its offer, negotiations have been completed with thirteen research associations, and offers of grants on a new basis have been made to and accepted by all of them. The associations in question as a whole are already assured of a thirty per cent increase in their resources as compared with those they commanded eighteen months ago, and, with one exception, each of these associations now enjoys an income of at least $£ 10,000$, the minimum figure which, even in a small industry, can be accepted as securing an assured future for an association. The total income of the Iron and Steel Industrial Research Council is now estimated at $£ 31,000$ as against $£ 16,000$ two years ago, while in the same period that of the Electrical and Allied Industries Research Association has increased from $£ 44,000$ to $£ 64,000$. The resources of the Cotton Industry Research Association have increased in one year from $£ 58,000$ to $£ 75,000$, those of the Paint Research Association from $£ 9,000$ to $£ 14,000$ and of the Flour Millers Research Association from $£ 7,600$ to $£ 13,000$.

These increases are due more to industrial support than to Government grants, and in aggregate, if the thirteen associations earned the maximum grant offered, their income would be double the aggregate of eighteen months ago, and three-fifths of this would come from industrial contributions. The work of these research associations themselves, however, touches almost every aspect of our national, and not merely of our industrial, life. For examples, we may refer to its bearing on foodstuffs of all kinds. Thus the Cocoa, Chocolate, Confectionery and Jam Trades Research Association is devising scientific means for ensuring that chocolate creams are evenly coated with chocolate, for preventing the fading of confectionery through exposure in the shop window, and is also studying the jellying properties of different types of oranges and the complicated processes of marmalade manufacture to ensure that the best possible marmalade reaches our breakfast table. The Food Manufacturers' Research Association has studied the resistance of bacteria to salt and saltpetre, and suggested a method of preventing certain defects in bacon and hams. The same Research Association has also found the true explanation of sausages losing their fresh appearance and becoming paler under certain conditions of storage.
Important work carried out by the Flour Millers Research Association has led to better knowledge of our most important foodstuff-bread. Apparatus has been developed for measuring the viscosity (or 'stickiness') of doughs and its elasticity (or 'springiness'), and attempts are being made to correlate the results of such measurements with the behaviour of dough in the bakehouse. Large-scale trials have proved that the hot aeration process developed by the Association improves very markedly the baking quality both of wheat flour and wheatmeal, sterilises the flour against mites, and partly sterilises it against bacteria, as well as improving the handling and character of the flour.

Other work of the research associations has an important bearing on clothing. Such, for example, is that of the Wool Industries Research Association on the development of a process for the production of unshrinkable wool, or on the scouring of wool, or again, the work of the Cotton Industry Research Association not only on cotton but also on silk and rayon and the mixed fabrics which are rapidly growing in popularity. The work of the Linen Industry Research Association, too, not merely bears on clothing but in the extension of the Sandringham experiment touches on agriculture also. A novel type of linen yarn is being developed, and other work is concerned with the protective treatment of linen materials exposed to the weather, and the fundamental investigation of the properties of sisal fibre.

The work of the Launderers' Research Association on detergent efficiency touches the housewife quite as closely, while that of the Boot, Shoe and Allied Trades' Research Association on the effect of perspiration on the wear of shoes has afforded unexpected indication of the state of a person's health in the condition of his footwear, tendencies towards rheumatism, or gout or diabetes having been detected in this way. Other materials besides leather which go to the making of shoes have been investigated by the same Association, while investigations of the Leather Manufacturers' Research Association have covered the preservation of leather from attack by micro-organisms, the evaluation of sole leather, use of leather for soundabsorption and also its use in conjunction with 'anti-ice' equipment for aeroplane wings.

The British Electrical and Allied Industries Research Association is carrying out work on underground cables which should permit the maximum loading within the limits of safety. Overhead line conductors are also receiving attention, as well as the prevention of failure in telephone and pilot cables in the ground around sub-stations, the reduction of the resistance of earth electrodes, surge phenomena, transformer noise and the 
interference caused to broadcast listening by the normal operation of electrical apparatus, such as vacuum cleaners, electric lifts, trolley buses, etc.

These investigations touch on both the amenities and the necessities of everyday life, and similarly the work of the Paint Research Association affects not merely industrial interests but also ordinary domestic life, where paints or varnishes or inks are required for many purposes. The Rubber Research Association is contributing to the requirements of the automobile industry as well as to those of the food industry for tubing, tank linings, sealing rings, etc., and has developed, for example, a greatly improved cider hose. Rubber joints for gas mains which will withstand the vibration due to modern traffic conditions are also being developed in collaboration with the gas industry. The Scientific Instrument Research Association has designed a remarkable new lens for use as a spectrographic object glass which should be more than twice as rapid as any lens previously used for astronomical spectrographical work. The supply of a lens of this design to the Mount Wilson Observatory should much increase the range within which remote nebulæ can be investigated, and is a notable triumph for the Association, which has also evolved a detailed technique for the production of very stable mirrors. Reference was made to this lens in Dr. G. E. Hale's article on the 200-inch telescope in NATURE of February 8 , and we hope to print a fuller account of it shortly.

If such research associations as those for the non-ferrous metals or refractories have made contributions of less direct interest to the man in the street, their indirect influence through industry has been no less important. The work of the research associations is, however, only one of the ways in which the Department is serving the needs of the community. Equally important contributions are being made by its own special research stations and boards. At the National Physical Laboratory an attempt is being made to devise a formula from which the best lighting for any industrial occupation can be deduced. Investigations are also being made to discover the best colour for the light from luminous discharge lamps used for street-lighting, and the best types of artificial daylight lamp for colour-matching purposes.

Other work at the National Physical Laboratory has been concerned with the measurement and reduction of noise, while in its Aerodynamics Department and the William Froude Laboratory problems bearing on the design of aeroplanes and ships are being investigated. Atmospheric pollution is watched over by a special committee which is endeavouring to complete our knowledge of the nature and extent of pollution in industrial areas, while the Water Pollution Research Board has initiated many important investigations and surveys regarding sewage purification, the disposal of industrial effluent and the pollution of rivers and estuaries. In particular, conditions have been worked out for the purification of effluents from dairies and milk product factories which are now being tested on a large scale. Important dental investigations have also been carried on by the Department, including promising attempts to find a synthetic resin substitute for dental vulcanite.

The Department is also responsible for work which has an important bearing on safety on the roads, as, for example, the study of glare in street lighting, the evaluation of glare from motor-car headlights, or the use of coloured headlight beams for driving in fog. Other illumination research bears on industrial health and efficiency, or on problems of mine light. ing. Investigations are also carried out to obtain more accurate data, especially for radiation and convection, as a basis for the scientific design of furnaces.

The Chemical Research Laboratory, like the National Physical Laboratory, has made contributions over a very wide field, from synthetic resin and new drugs, to corrosion of metals, the investigation of rubber, tar and high-pressure reactions. Merely to enumerate many of the other research boards should indicate how wide is the Department's contribution to the national welfare through the work of its own special stations. Space does not permit reference to the work of the Fuel Research Board, of the Steel Structures Research Committee, of the Radio Research Board, the Building Research Station, the Road Research Station and the Forest Products Research Board; but brief reference must be made to the work of the Food Investigation Board, which supplements that of the various research associations concerned with food. In its own stations the Board has made important contributions in the curing of bacon, the storage of fish, preservation of fruit in wrappers and the kippering process and the canning of fruit and vegetables, and the Report shows how well the Department is planning the national effort in this important field to prevent duplication of labour or waste of natural resources.

The Report is thus impressive not only for the picture it gives of the way in which science affects every department of our life, but also for the object lesson it affords of the need of some central organisation which can plan and co-ordinate, if not direct, the research effort of the nation, so as to secure the most efficient service of our myriad needs and the handling of our major problems from a national, and not a sectional, point of view. 